\title{
Analisis Kebutuhan pada Bahan Ajar Penelitian dan Penulisan Sejarah di Sekolah Menengah Atas (SMA)
}

\author{
Nia Ulfia Krismawati ${ }^{(1)}$, Warto $^{(2)}$, Nunuk Suryani ${ }^{(3)}$ \\ ${ }^{1}$ S2 Pendidikan Sejarah, Universitas Sebelas Maret, Surakarta \\ ${ }^{2,3}$ Professor S2 Pendidikan Sejarah, Universitas Sebelas Maret, Surakarta \\ Email: ${ }^{1}$ niaulfia5544@gmail.com, ${ }^{2}$ warto_file@yahoo.com, \\ ${ }^{3}$ nunuksuryani@staff.fkip.uns.ac.id
}

\section{Tersedia Online di}

http://www.jurnal.unublitar.ac.id/ index.php/briliant

\begin{tabular}{l}
\hline Sejarah Artikel \\
\hline Diterima pada 10 Juli 2018 \\
Disetuji pada 21 Juli 2018 \\
Dipublikasikan pada 13 Agustus \\
2018 Hal. 300-311 \\
\hline
\end{tabular}

\section{Kata Kunci:}

bahan ajar pengayaan, projectbased learning, metode penelitian dan penulisan sejarah, sekolah menengah atas, ponorogo.,

\section{DOI:}

http://dx.doi.org/10.28926/briliant .v3i3.202

\begin{abstract}
Abstrak: Penelitian ini bertujuan untuk menganalisis tingkat kebutuhan peserta didik di Sekolah Menengah Atas (SMA) terhadap bahan ajar sejarah. Metode penelitian yang digunakan adalah penelitian pengembangan dengan berpedoman pada desain instruksional 4D (define, design, develop, and dissemination). Subjek dalam penelitian ini adalah siswa SMA kelas X IPS peminatan. Berdasarkan hasil observasi, wawancara, dan penyebaran kuisioner, buku paket sejarah telah digunakan dalam proses pembelajaran dan terbukti berhasil membantu peserta didik dalam mencari informasi. Namun, di sisi lain terdapat beberapa permasalahan yang muncul dari penggunaan buku paket seperti materi yang disajikan masih umum, hanya berfokus pada aspek kognitif, kurang mendetail, dan belum menyajikan kegiatan belajar aktif bagi peserta didik. Penelitian ini bertujuan untuk melakukan analisis kebutuhan peserta didik, kurikulum, dan kondisi kelas guna menemukan solusi dalam bentuk pengembangan produk pembelajaran. Hasil penelitian menunjukkan bahwa, (1) terdapat permasalahan dalam penggunaan buku paket sejarah sebagai sumber utama, (2) peserta didik membutuhkan bahan ajar pengayaan yang mengintegrasikan sejarah lokal, (3) penggunaan model project-based learning dapat menjadi alternatif strategi untuk pembelajaran aktif, dan (4) sejarah gemblak dapat dijadikan sebagai studi kasus penelitian dengan beberapa pertimbangan
\end{abstract}

Sejarah lebih dari sebuah kisah atau peristiwa yang terjadi di masa lalu. Ketika terdapat pernyataan terkait sejarah adalah peristiwa masa lampau, pertanyaan yang kemudian muncul adalah kejadian seperti apa yang dapat disebut sebagai sejarah? Apakah setiap aktivitas manusia harus dikategorikan sebagai sejarah? Dalam cara praktis dan metodologis, sejarah berarti aktivitas manusia dalam periode waktu dan tempat tertentu (Abdullah, 1985). Sejarah memiliki dua makna yaitu: 1) ekstern, sejarah adalah rotasi waktu, serangkaian peristiwa, dan perubahan kekuasaan: 2) intern, sejarah adalah alasan kritis dan upaya yang hatihati untuk mencari kebenaran, memahami sebab dan akibat, asal-usul segalanya, dan pengetahuan mendalam tentang mengapa dan bagaimana peristiwa itu bisa terjadi (Suharto: 2003: (Hamid, 2015). Sejarah adalah proses interaksi yang terjadi 
secara terus menerus antara sejarawan dan fakta-faktanya serta dialog tak berujung antara masa sekarang dan masa lalu (Carr, 1982: (arif, 2009). Sejarah sebagai disiplin ilmu pada dasarnya adalah penemuan dan interpretasi tanda-tanda masa lalu serta konvensi. Tujuan utama mempelajari sejarah adalah memotivasi peserta didik untuk memahami sikap manusia di masa lalu, sekarang, dan masa depan yang mengajarkan mereka bagaimana berperilaku dalam masyarakat nyata

Kriteria utama dalam perencanaan proses pembelajaran sejarah yang sukses terdiri dari 1) penggunaan metode pengajaran yang efektif berarti mampu mendorong peserta didik untuk memiliki rasa bertanggung jawab, ketrampilan imajinasi yang tinggi, dan melibatkan mereka dalam proses pembelajaran (active learning): 2) kegiatan dan sumber belajar yang melibatkan peserta didik dan memungkinkan mereka untuk mengambil tanggung jawab secara individual: 3) kegiatan pembelajaran yang merangsang ketrampilan dan mendorong perkembangan serta memungkinkan kegiatan diskusi di antara peserta didik (Smith, 2010). Berdasarkan kriteria tersebut, cara yang efektif untuk memahami sejarah adalah melakukan penelitian, mengumpulkan sumber, menghubungkan peristiwa, dan menafsirkan apa yang sebenarnya terjadi di masa lalu. Dengan melakukan kerja nyata melalui aplikasi materi yang telah difahami dapat memotivasi baik dalam jangka pendek maupun jangka panjang (Retnawati, 2017).

Menurut Colingwood (1973), pembelajaran sejarah yang ideal adalah mampu mendorong peserta didik untuk melakukan kegiatan penelitian atau penyelidikan. Hal ini memungkinkan mereka untuk membuat pertanyaan kritis dan menemukan jawabannya melalui pencarian sumber sejarah (arif, 2009). Dalam silabus sejarah SMA, materi "penelitian dan penulisan sejarah" merupakan salah satu materi yang harus diampu oleh siswa kelas X IPS Peminatan. Adapun tujuan dari materi ini adalah memotivasi peserta didik untuk memahami secara mendalam terkait metode penelitian dan penulisan sejarah serta bertindak layaknya seorang sejarawan. Pada kenyataannya, sejarawan tidak hanya orang yang memiliki kemampuan, memahami banyak teori, dan telah berpengalaman dalam subjek sejarah. Namun, sejarawan merupakan orang yang menciptakan karya sejarah, seperti, buku sejarah, esai, dan makalah. Menurut Kuntowijoyo, setiap orang bisa menjadi sejarawan. Terdapat tiga kelas sejarawan yang diklasifikasikan berdasarkan pendidikan, (1) sejarawan profesional yang lulus dari departemen sejarah, (2) sejarawan disiplin ilmu lain yang memiliki kemampuan dalam menulis sejarah sehingga memerlukan metode dan keterampilan menulis, dan (3) sejarawan dari masyarakat yang tinggal di daerah tertentu yang menulis sejarah mereka sendiri. Berdasarkan pengelompokan sejarawan, materi penelitian dan penulisan sejarah akan mempersiapkan peserta didik untuk menjadi sejarawan profesional yang dapat menciptakan karya sejarah.

Dalam proses pembelajaran sejarah di SMA Ponorogo, ditemukan beberapa permasalahan, meliputi: (1) penggunaan strategi pembelajaran yang mengarah pada teacher-centered. Hal ini terbukti pada penggunaan metode ceramah di setiap pertemuan yang berdampak pada pembelajaran pasif dan tidak sesuai dengan prinsip kurikulum 2013: (2) penggunaan sumber belajar berupa buku paket sejarah. Berdasarkan analisis yang telah dilakukan, buku paket merupakan sumber utama dan satu-satunya dalam proses pembelajaran. Selain itu, buku paket belum mampu memberikan penjelasan materi secara rinci atau masih bersifat umum serta belum menyediakan kegiatan belajar aktif: (3) belum terdapat 
upaya dalam mengintegrasikan pembelajaran dengan sejarah lokal Ponorogo ke dalam proses pembelajaran sejarah. Pada realitanya, Ponorogo merupakan kabupaten yang kaya akan sejarah dan kearifan lokal sehingga dapat menjadi sumber inspirasi bagi peserta didik: 4) rendahnya pemahaman dan ketrampilan dalam melakukan penelitian dan penulisan sejarah lokal. Hal ini terlihat pada bentuk penugasan berupa pengerjaan soal-soal dalam buku paket yang menekankan pada aspek kognitif saja: 5) rendahnya literasi sejarah lokal peserta didik yang disebabkan oleh tidak adanya ruang bagi sejarah lokal dalam silabus sejarah di SMA.

Beberapa permasalahan di atas dapat diselesaikan melalui pengembangan strategi pembelajaran berupa metode, model, dan media pembelajaran sejarah. Berdasarkan penelitian dari Suharso (2017) menunjukkan bahwa pengembangan media pembelajaran berupa bahan ajar sejarah berbasis sejarah lokal dapat meningkatkan minat peserta didik pada pembelajaran sejarah dikarenakan adanya kedekatan emosional dan kultural. Penelitian yang kedua dari Ningsih (2015) menunjukkan bahwa penggunaan bahan ajar dalam bentuk modul dapat meningkatkan prestasi belajar peserta didik melalui pembelajaran aktif dengan pendekatan student-centered. Penelitian ketiga dari Novianti, dkk (2014) menunjukkan bahwa bahan ajar sejarah dapat dijadikan sebagai sarana dalam menanamkan nilai-nilai karakter dan kearifan lokal yang berada di lingkungan peserta didik. Berdasarkan beberapa penelitian terdahulu dapat disimpulkan bahwa pengembangan media pembelajaran berupa bahan ajar sejarah dapat menjadi solusi permasalahan yang efektif. Terlebih lagi, penggunaan bahan ajar dapat menekankan ketiga aspek penting dalam pembelajaran yaitu aspek kognitif, afektif, dan psikomotor.

Pada penelitian ini, pengembangan bahan ajar sejarah menjadi pilihan dalam mengatasi permasalahan yang terjadi dalam proses pembelajaran. Pemilihan solusi didasarkan pada kebutuhan peserta didik melalui penyebaran kuisioner, wawancara, dan observasi kelas. Bahan ajar yang dikembangkan sebagai solusi permasalahan dilakukan dengan mengintegrasikan sejarah lokal sebagai studi kasus penelitian. Selain itu, bahan ajar ini memanfaatkan salah satu pendekatan saintinfik yaitu project-based learning yang mengantarkan peserta didik pada pengerjaan sebuah proyek. Adapun bentuk penugasan dari bahan ajar yang dikembangkan yaitu penelitian dan penulisan sejarah lokal Ponorogo dengan tujuan meningkatkan pemahaman sejarah lokal dan ketrampilan dalam penelitian sejarah. Prinsip high order thinking skill (HOTS) dari kurikulum 2013 dapat tercapai dalam kondisi dimana peserta didik berperan aktif dalam memahami dan memadukan pengetahuan dengan pengalaman (Anderson \& Krathwohl: (Fitri, 2018). Hal ini mungkin dikuasai melalui kerja nyata yaitu kegiatan penelitian dan penulisan sejarah lokal.

Bahan ajar yang berfokus pada penelitian dan penulisan sejarah memungkinkan peserta didik untuk bekerja dan bertindak seperti sejarawan profesional. Dalam proses pembelajaran, peserta didik mendapatkan kesempatan untuk mengembangkan berbagai keterampilan seperti komunikasi, observasi, interpretasi dan mempertanyakan fakta atau kasus (Smith, 2010). Tingkat efektivitas penggunaan buku paket sejarah dan sumber belajar khususnya pada materi metode penelitian sejarah adalah kurang baik. Hal ini didasarkan pada belum tersedianya materi terkait teknik pengumpulan, pengolahan dan analisis 
data, serta sistematika penulisan sejarah yang penting untuk dipahami. Berdasarkan hal tersebut, pengembangan buku pengayaan pada materi penelitian dan penulisan sejarah adalah solusi untuk memfasilitasi peserta didik dalam mendapatkan pemahaman secara mendalam. Adapun alasan dari pengintegrasian sejarah lokal sebagai materi tambahan dikarenakan rekomendasi sebagai cara efektif dalam memahami sejarah secara menyeluruh. Dengan mengumpulkan sumber primer, memahami asal-usul, dan tujuan sejarah memungkinkan peserta didik untuk mempertanyakan mengapa orang melakukan hal yang dianggap irrasional pada masa sekarang.

Ponorogo memiliki sejumlah sejarah lokal seperti Kerajaan Bantar Angin, Warok, Gemblak, Bathoro Katong, Reyog, dan Larung Sesaji. Beberapa jenis sejarah lokal tersebut dapat dijadikan sebagai studi kasus penelitian dan penulisan sejarah. Berdasarkan wawancara dan kuisioner, secara umum peserta didik mengetahui dua sampai tiga jenis sejarah lokal Ponorogo. Adapun salah satu sejarah lokal yang tidak diketahui bahkan telah dilupakan oleh masyarakat Ponorogo yaitu sejarah gemblak. Sejarah ini mengandung nilai akan perjuangan sekelompok masyarakat dalam membangun identitas lokal melalui kesenian reyog. Sejarah Gemblak dapat menjadi sarana dalam memahami peristiwa lokal dan mengaplikasikan nilai-nilai yang terkandung di dalamnya pada kehidupan nyata. Pengembangan bahan ajar sejarah ini dilakukan dengan mengintegrasikan sejarah gemblak sebagai studi kasus penelitian. Alasan pemilihan sejarah gemblak sejarah, antara lain: 1) merupakan peristiwa yang memberikan pengaruh pada kehidupan masyarakat luas: 2) kurangnya literasi atau penelitian yang berkaitan dengan gemblak sejarah: 3) memiliki nilai edukatif dan inspiratif: dan 4) mempunyai hubungan erat dengan dengan sejarah perkembangan dan pelestarian reyog sebagai identitas lokal Ponorogo. Dengan mempelajari sejarah gemblak memungkinkan peserta didikuntuk meningkatkan pemahaman sejarah lokal.

Adapun tujuan dari penelitian ini, meliputi: 1) menganalisis tingkat kebutuhan peserta didik dan guru di dalam kelas sejarah: 2) memahami permasalahan dalam proses pembelajaran dan memberikan solusi terkait permasalahan tersebut: 3) mengembangkan media pembelajaran dalam bentuk bahan ajar penelitian dan penulisan sejarah melalui project-based learning untuk meningkatkan keterampilan literasi sejarah lokal peserta didik. Harapan dari penelitian ini adalah memfasilitasi peserta didik untuk mendapatkan informasi detail tentang pembelajaran sejarah dan mendukung mereka untuk meningkatkan keterampilan literasi sejarah lokal. Selain itu, penelitian ini berguna untuk memotivasi peserta didikdalam mencapai kesadaran sejarah melalui pemahaman makna dan nilai sejarah lokal. Studi ini juga memperkenalkan kepada peserta didikpada keberadaan sejarah lokal yang mempunyai hubungan erat dengan perkembangan kesenian reyog serta menginspirasi generasi muda dalamperjuangan melestarikan identital lokal yang ada.

\section{METODE}

Penelitian ini menggunakan metode penelitian dan pengembangan berdasarkan desain instruksional 4D (define, design, develop, and disseminate). Define, tujuan dari tahap ini adalah untuk menetapkan dan mendefinisikan persyaratan instruksional. Lima langkah dari tahap ini adalah analisis awal, analisis kebutuhan peserta didik, analisis tugas, analisis konsep, dan menentukan 
tujuan instruksional. Desain, tujuan dari tahap ini adalah merancang prototipe bahan ajar. Empat langkah dari tahap ini adalah tes yang mengacu pada kriteriakriteria konstruksi, pemilihan media, pemilihan format, dan desain awal. Develop, bertujuan untuk memodifikasi prototipe bahan ajar melalui validasi ahli dan uji coba lapangan (Thiagaran, 1974). Panduan desain instruksional ini untuk mengembangkan bahan ajar sejarah berdasarkan pada analisis kebutuhan siswa, kurikulum, dan proses belajar.

Teknik pengumpulan data yang digunakan, meliputi: 1) kuesioner, mengetahui kebutuhan peserta didik dalam proses pembelajaran sejarah: 2) observasi, mengetahui kondisi dan masalah dalam pembelajaran sejarah: 3) wawancara kepada guru dan peserta didik. Penelitian ini dilakukan di SMAN Ponorogo, kelas $\mathrm{x}$ IPS Peminatan. Adapun pemilihan lokasi penelitian berdasarkan permasalahan yang muncul dalam pembelajaran sejarah dan kedekatan historis dengan sejarah lokal Ponorogo. Berdasarkan snalisis kebutuhan pada peserta didik dapat disimpulkan bahwa mereka membutuhkan materi tambahan berupa buku pengayaan yang berhubungan dengan metode penelitian sejarah dan penulisan sejarah secara sistematis dan memungkinkan praktek penelitian dan penulisan sejarah.

\section{HASIL}

Permasalahan yang muncul dalam proses pembelajaran sejarah di SMA Ponorogo adalah penggunaan sumber belajar, strategi pembelajaran, dan alokasi waktu pembelajaran. Berdasarkan analisis menunjukkan bahwa buku paket sejarah mempunyai peranan penting dalam membantu peserta didik dan guru selama proses pembelajaran berlangsung. Dapat dikatakan pendekatan pembelajaran yang sering diterapkan adalah teacher-centered dan textbookcentered. Pentingnya peran buku paket sebagai sumber utama menjadi hal yang harus diperhatikan dalam artian mampu memenuhi kebutuhan informasi. Terdapat beberapa kekurangan pada buku paket yang selama ini digunakan, meliputi, materi yang bersifat umum, tidak tersedia instruksi pembelajaran aktif, minimnya contoh-contoh nyata, dan tidak adanya ruang bagi materi sejarah lokal. Sebagai contoh pada materi "penelitian dan penulisan sejarah", buku ini menyediakan informasi terkait definisi dan metode penelitian sejarah. Jika diperhatikan, materi penelitian dan penulisan sejarah mempunyai tingkat kesulitan yang tinggi mengingatkondisi peserta didik yang masih berada di kelas satu SMA. Buku paket sejarah yang digunakan belum menyediakan materi yangdirasa penting dan rinci seperti teknik pengumpulan dan pengolahan sumber sejarah serta sistematikapenulisan sejarah yang dilakukan pada tahap historiografi. Di sisi lain, buku ini belummenyediakan lembar kerja yang mengarahkan peserta didik pada pengerjaan proyek penelitian sejarah.

Permasalahan yang kedua, yaitu penggunaan strategi pembelajaran yang belum sesuai dengan prinsip kurikulum 2013. Penggunaan strategi pembelajaran di SMAN Ponorogo didominasi oleh metode ceramah dengan pendekatan teachercentered. Pemanfaatan strategi ini berdampak pada rendahnya keaktifan, kreativitas, dan kekritisan peserta didik. Jika dilihat berdasarkan kondisi ideal dari proses pembelajaran sejarah, guru tidak hanya bertugas untuk mentransfer pengetahuan dalam bentuk cerita atau fakta sejarah tetapi juga diharuskan untuk mendorong peserta didik dalam kegiatan mengamati, menganalisis, dan 
merekonstruksi peristiwa sejarah berdasarkan pengetahua yang didapatkan sebelumnya (Romadi \& Ganda, 2017). Pendekatan saintifik meliputi, seperti project-based learning, problem-based learning, dan discovery learning telah direkomendasikan oleh kurikulum 2013 sebagai strategi efektif dalam pembelajaran sejarah. Permasalahan yang ketiga, yaitu alokasi waktu pembelajaran. Pada materi penelitian dan penulisan sejarah, peserta didik hanya mendapatkan waktu 3x45 menit. Hal ini dirasa kurang mengingat proses pengerjaan proyek penelitian membutuhkan lebih banyak waktu. Maka dari itu guru yang berperan sebagai fasilitator diharuskan mempunyai profesionalitas yang tinggi dan bijaksana dalam mengatur waktu belajar yang mendukung keberhasilan pengerjaan proyek.

Hasil temuan di atas menjadi pertimbangan dalam pencarian solusi permasalahan yang terjadi. Beberapa hal yang ditekankan pada proses ini adalah menganalisis karakteristik, kompetensi, dan pengetahuan awal dari peserta didik. Permasalahan yang ada berdampak pada rendahnya pemahaman peserta didik dalam proses penelitian dan penulisan sejarah. Hal ini terlihat pada kegiatan penentuan topik dan jenis sumber sejarah, proses pengumpulan dan pengolahan data,interpretasi, dan bentuk penulisan sejarah yang dihasilkan. Dalam kenyataanya, peserta didik merasa kesulitan dalam memahami beberapa materi, antara lain, menentukan sumber sejarah baik yang bersifat primer maupun sekunder, jenis teknik pengumpulan data sejarah, dan cara penulisan hasil penelitian secara sistematis. Berdasarkan analisis kebutuhan, dapat disimpulkan bahwa peserta didik membutuhkan bahan ajar pengayaan yang memungkinkan mereka dalam praktek penelitian dan penulisan sejarah.

Solusi berupa pengembangan bahan ajar penulisan sejarah mendapat respon baik dari peserta didik. Hasil kuesioner menunjukkan bahwa sebanyak 69,4\% siswa menyatakan sangat setuju dan 30,6\% mengatakan setuju. Sedangkan solusi yang kedua yaitu pemberian tugas dalam bentuk pengerjaan proyek penelitian sejarah lokal turut mendapat respon yang baik. Berikut ini merupakan hasil kuisioner terkait antusias peserta didik pada penugasan proyek penelitian dan penulisan sejarah lokal, meliputi, 55,6\% peserta didik menyatakan sangat antusias, $30,6 \%$ antusias, dan 7,2\% tidak antusias. Berdasarkan data ini, dapat disimpulkan bahwa pengembangan bahan ajar penulisan sejarah dan pemberian tugas akhir berupa pengerjaan proyek penelitian dan penulisan sejarah lokal disambut baik oleh peserta didik.

\section{Pengalaman Guru Dalam Penggunaan Bahan Ajar Sejarah}

Buku paket atau bahan ajar sejarah mempunyai peran penting dalam proses pembelajaran. Sekolah ini telah menggunakan buku teks sejarah selama bertahun-tahun dengan selalu menyeleksi kualitas buku berdasarkan kebeneran, kesuaian, dan kebermafaatan materi pembelajaran. Adapun alasan dari penggunaan buku teks untuk kelas sejarah adalah 1) membantu guru dalam proses pembelajaran sejarah, 2) membantu guru dalam proses menemukan informasi tambahan atau referensi, 3) membantu dalam proses evaluasi terhadap pemahaman siswa melalui pengerjaan soal-soal yang telah disediakan dalam buku paket. Meskipun begitu, guru mengaku bahwa penggunaan buku paket belum mampu memenuhi kebutuhan peserta didik secara maksimal. Hal ini dikarenakan 
seringkali penyediaan materi yang masih bersifat umum dan kurang memberikan ruang bagi partisipasi peserta didik.

\section{Persepsi Guru Pada Pengembangan Bahan Ajar Penelitian dan Penulisan Sejarah Lokal}

Ponorogo merupakan kabupaten yang kaya akan sejarah lokal dan kearifan budaya sehingga menjadi wadah yang tepat bagi peserta didik dalam mendapatkan sumber pembelajaran. Penelitian ini berusaha mengintegrasikan salah satu sejarah lokal Ponorogo yaitu "sejarah gemblak". Pemilihan topik ini didasarkan pada rendahnya pengetahuan peserta didik pada peristiwa lokal yang mempunyai hubungan dengan masa kini. Sejarah gemblak adalah salah satu sejarah lokal Ponorogo yang mempunyai keterkaitan dengan kehidupan masyarakat elit dan kekayaan budaya. Gemblak adalah sebutan bagi seorang anak laki-laki berusia 10-17 tahun yang berperan sebagai asisten warok dan dikenal sebagai aktor budaya yaitu penari jatil dalam kesenian reyog. Sebelum tahun 1980-an, kebiasaan menggemblak dianggap sebagai tradisi dan bahkan menjadi salah satu cara dalam menentukan status sosial masyarakat di Ponorogo. Dalam kenyataannya, tradisi ini mempunyai dampak baik dalam kehidupan warok, gemblak, maupun masyarakat secara luas. Jika dilihat dari segi negatif, menggemblak merupakan bentuk praktik kekuasaan, hegemoni, dan tergolong pada jenis perilaku tradisional berdasarkan teori tindakan rasional Weber yang kurang sejalan dengan nilai dan norma masyarakat. Sedangkan dari sisi positif, tradisi ini mempunyai hubungan erat dengan perkembangan dan pelestarian identitas lokal Ponorogo yang dikenalsebagai kesenianreyog.

Dalam sejarah gemblak, terdapat nilai-nilai perjuangan sekelompok masyarakat dalam membangun identitas lokal yang pada masa kini menjadi kekayaan budaya. Sejarah ini dapatmembawa peserta didik pada pemahaman sejarah lokal dan menanamkan rasa cinta pada kebudayaan yang ada. Rendahnya kesadaraan sejarah lokal peserta didik berdampak pada semakin surut dan hilangnya nilai budaya Ponorogo. Hal ini terbukti pada rendahnya kecintaan peserta didik pada kesenian reyog yang menjadi identitas lokal. Berdasarkan hasil wawancara sebagian besar peserta didik menyatakan kurang tertarik dan tidak memahami makna dari kegiatan budaya yang selalu diselenggarakan oleh Kabupaten Ponorogo dalam setiap tahunnya. Hal ini menjadi pertimbangan dalam menentukan solusi terbaik yaitu melalui pembelajaran sejarah lokal yang memungkinkan kegiatan literasi untuk dilakukan. Adapun pendapat guru terkait pengintegrasian sejarah gemblak dalam pembelajaran sejarah Indonesia terlihat pada wawancara yang telah dilakukan. Guru sejarah (NN) membuat pernyataan:

"Sejarah gemblak dapat menjadi materi dalam kelas sejarah, tetapi kita sebagai pengajar harus bersikap bijak dengan cara menyaring sisi positif sejarah dan disesuaikan dengan zaman sekarang. Tentunya kegiatan ini dapat mendukung keterampilan seni siswa dan memperkaya pengetahuan tentang cara menjaga dan melestarikan budaya. Pada zaman dulu, sejarah gemblak dikenal sebagai praktek yang kurang sesuai dengan norma yang ada, jadi kita harus mengajar dengan hati-hati dan bijaksana. Sebenarnya, materi ini baik untuk mendorong siswa melakukan 
penelitian karena sebagian besar siswa tidak tahu tentang sejarah ini. Bahkan, itu bisa menjadi inspirasi terutama siswa laki-laki tentang peran anak muda di reyog sebelumnya (6 Februari 2018)."

Guru sejarah di SMAN Ponorogo menyatakan setuju dengan pengintegrasian sejarah gemblak sebagai studi kasus penelitian dengan catatan menyesuaikan penelitian dengan kondisi masa sekarang. Selain itu, pemilihan materi harus dikembangkan berdasarkan kompetensi inti dan kompetensi dasar yang tertera dalam silabus sejarah kelas X IPS Peminatan kurikulum 2013. Pengembangan bahan ajar ini diperkuat dengan melakukan diskusi dengan guru sejarah SMA dan para ahli pendidikan yang terdiri dari ahli materi, ahli pengembangan bahan ajar, dan ahli instrumen penilaian. Selain itu perancangan bahan ajar diharapkan dapat melibatkan peserta didik dalam kegiatan diskusi terkait permasalahan yang terjadi. Guru sejarah (EN) menyatakan,

"Sejarah gemblak adalah sejarah yang penting untuk dipelajari karena sudah menjadi bagian dari masyarakat Ponorogo. Menurut sejarah, praktek gemblak sudah dilakukan sejak ratusan tahun lalu dan hilang baru sekitar 20 tahunan kemaren. Meskipun banyak orang yang menganggap di sejarah ini ada sisi gelapnya dalam artian disebut dengan praktek homo, namun sisi positif yang harus dipelajari oleh siswa adalah bagaimana peran mereka dalam memperjuangkan kesenian reyog yang sekarang menjadi identitas lokal. Sangat disayangkan jika kesenian ini kembali diklaim oleh orang lain. Sebagai warga yang baik memang kita harus menjaga budaya nenek moyang (6 Februari 2018)."

Berdasarkan data di atas dapat simpulkan bahwa guru sejarah di SMA Ponorogo, menyatakan setuju dan mendukung pengembangan bajan ajar sejarah penelitian dan penulisan sejarah gemblak.

\section{PEMBAHASAN}

Berdasarkan analisis kebutuhan dari observasi, penyebaran kuisioner, dan wawancara, dapat disimpulkan bahwa buku teks sejarah yang selama ini digunakan dalam proses pembelajaran kurang bermanfaat secara maksimal. Terutama pada materi penelitian dan penulisan sejarah yang merupakan salah satu materi inti dalam silabus. Pembelajaran sejarah, belum mengintegrasikan sejarah lokal sebagai program pengayaan bagi peserta didik. Penggunaan sejarah lokal memberikan siswa kesempatan untuk mendapatkan pengalaman tangan pertama dengan meningkatkan kesadaran sejarah (Oguzan, 2015). Guru dan peserta didik membutuhkan materi tambahan yang mendukung buku teks dalam rangka mendapatkan pemahaman secara mendalam. Bahan ajar pengayaan yang ditawarkan berbentuk modul yang merupakan salah satu bentuk bahan ajar yang dikembangkan secara utuh dan sistematis yang mendukung peserta didik dalam menguasai pembelajaran secara khusus (Daryanto, 2013). Selain itu, bahan ajar ini didesain berdasarkan sintak atau langkah pembelajaran berbasis project-based yang mampu mengkoneksikan muatan akademik dengan konteks dunia nyata. Sumarmi (2012) menyatakan bahwa project-based learning dapat menyediakan 
lingkungan belajar aktif dan mendorong peserta didik dalam mengkonstruksi pengetahuan dan ketrampilan secara mandiri (Hosnan, 2014).

Project-based learning adalah strategi pembelajaran memberdayakan peserta didik untuk menunjukkan pemahaman baru mereka melalui berbagai pengerjaan proyek (Hosnan, 2014). Model ini menawarkan cara pembelajaran yang melibatkan siswa di sekolah melalui pengalaman mereka dengan belajar secara otentik (See, 2015). Pembelajaran berbasis proyek cocok untuk kegiatan pembelajaran literasi seperti membaca, meneliti, dan menulis sejarah. Pembelajaran berbasis proyek adalah model pembelajaran dengan pendekatan isuisu otentik yang memungkinkan peserta didik untuk membangun pengetahuan mereka sendiri, mengembangkan keterampilan intelektual, dan meningkatkan kepercayaan diri dalam bentuk proyek (Hosnan, 2014). Strategi ini mengkontekstualisasikan pembelajaran dengan menfasilitasi peserta didik untuk menciptakan produk atau pemecahan masalah yang ada. Kegiatan pembelajaran pembelajaran berbasis proyek terdiri dari desain, pemecahan masalah, penyelidikan, dan pengambilan keputusan. Dalam pengerjaan proyek, siswa akan melakukan kegiatanmembaca, memilah informasi, membandingkan dan memecahkanpermasalahanyang berpusat pada tema yang relevan dengan konten spesifik (Thitivesa, 2014). Pendekatan ini adalah salah satu rekomendasi kurikulum 2013 yang memotivasi peserta untuk menjadi aktif, kritis, dan kreatif. Pendidikan Indonesia telah ditekankan bahwa yang dibutuhkan dalam kegiatan pengajaran saat ini harus sejalan dengan unsur-unsur yang dibutuhkan dalam keterampilan abad ke-21 yang terdiri dari, pembelajaran dan keterampilan inovatif, keterampilan informasi, media, dan teknologi. Hal ini sejalan dengan pembelajaran yang mendukung seperti kerja tim, teknologi, keterampilan proyek, dan keterampilan pemecahan masalah.

Dalam kenyataannya, pengajaran sejarah lokal memiliki masalah utama yaitu waktu dan sumber tertulis yang terbatas. Ketika sumber tertulis tidak cukup untuk memberikan informasi, maka guru perlu menjelaskan tentang sejarah lisan dengan mendapatkan sumber dari tangan pertama. Metode ini dapat mengubah fokus sejarah dan membuka penelitian baru yang memungkinkan guru dan siswa untuk berkomunikasi dan berdiskusi. Metode sejarah lisan cocok untuk proses pembelajaran di sekolah dengan memahami kerangka kerja dan analisis konseptual. Misalnya, sebelum melakukan wawancara, para siswa harus mencari informasi tentang orang yang diwawancarai dengan memperhatikan beberapa hal yang terdiri dari: pertama, mereka adalah aktor sejarah: dan kedua, mereka memiliki ingatan yang baik (Hamid, 2015). Keakuratan data sangat mempengaruhi proses interpretasi dan hasil penelitian. Kesempatan ini dapat meningkatkan keterampilan kritis siswa dan memotivasi mereka untuk belajar bagaimana menentukan sumber primer dan sumber sekunder. Ada banyak topik sejarah lokal yang dapat ditinjau oleh siswa, seperti sejarah industri atau kearifan lokal, hubungan sosial di antara masyarakat, dialek dan budaya, perubahan keluarga, dampak perang, dan lain-lain (Thompson, 2012). Melalui berbagai topik sejarah lokal, ini memberikan kesempatan kepada siswa untuk melakukan penelitian sederhana dengan melakukan wawancara terhadap aktor sejarah atau sumber tangan pertama dan mengamati warisan sejarah seperti artefak yang merupakan hasil sejarah dan dokumen yang merupakan catatan dari sejarah (Notosusanto, 1975).

308 BRILIANT: Jurnal Riset dan Konseptual Volume 3 Nomor 3, Agustus 2018 
Pengembangan bahan ajar yang berfokus pada materi metodepenelitian dan penulisan sejarah.Menurut Garragham (1957), metode sejarah adalah aturan dan prinsip sistematis dalam mengumpulkan sumber-sumber sejarah, memproses dan mengajukan sintesis berdasarkan data yang telah dikumpulkan (Hamid, 2015). Pemahaman tentang makna dan metode sejarah adalah materi penting yang harus dimiliki oleh peserta didik. Ada berbagai bahan penting yang harus dipahami tentang penelitian sejarah dan penulisan yang terdiri dari 1) sumber sejarah termasuk sumber primer dan sekunder dalam bentuk tulisan, lisan, dan artefak yang membantu siswa untuk memilih tempat (di mana) dan siapa (sumber lisan): 2) teknik pengumpulan data meliputi wawancara, observasi, dan tinjauan literatur: dan 3) objektivitas dan subjektivitas dalam sumber sejarah (Notosusanto, 1975). Dengan menguasai materi-materi tersebut, para pembelajar siap untuk melakukan penelitian sejarah sederhana.

Bahan ajar ini dilengkapi dengan beberapa bagian sebagai berikut: 1) instruksi pembelajaran, memungkinkan peserta didik untuk belajar secara mandiri: 2) kelengkapan, materi yang terdapat di dalam modul didesain sedemikian rupa sehinggamampu memberikan informasi yang cukup bagi peserta didik: 3) adaptif, disesuaikan dengan perkembangan teknologi: 4) mudah digunakan, setiap instruksi dan memberikan informasi dapat membantu peserta didik dalam merespon dan mengakses pengetahuan berdasarkan keinginan. Penggunaan modul sekaligus dapat membantu seorang guru dalam proses pembelajaran, dikarenakan dikembangkan berdasarkan rencana pelajaran (RPP) (Permana, 2016). Modul dikembangkan untuk mewujudkan tujuan kompetensi sekolah baik bersifat kompetensi inti maupun kompetensi dasar. Jika dilihat dari tingkat fleksibilitasnya, modul tergolong pada bahan ajar yang memiliki fleksibilitas yang sangat tinggi karena dikembangkan berdasarkan analisis kebutuhan kurikulum, kondisi peserta didik, dan proses belajar mengajar (Daryanto, 2013). Pada sekolah menengah atas (SMA) terutama di kelas satu, tentunya penggunaan modul harus didukung oleh peran seorang guru sebagai fasilitator.

Berdasarkan analisis, media pembelajaran dalam bentuk modul cocok untuk mendukung sumber utama (buku teks) dalam pembelajaran sejarah. Produk ini diyakini dapat membantu peserta didik untuk belajar secara mandiri, kritis, dan aktif. Keseluruhan guru sejarah di SMA Ponorogo menyatakan setuju dengan penggunaan modul sebagai materi tambahan yang mengintegrasikan sumber sejarah lokal sebagai studi kasus. Peserta didikpun menyatakan setuju dengan pengembangan buku pengayaan guna menemukan informasi mendalam dan memungkinkan mereka untuk melakukan kerja nyata dalam bentuk penelitian dan penulisan sejarah. Penelitian ini memanfaatkan salah satu sejarah lokal Ponorogo yang bernama gemblak sejarah untuk dijadikan studi kasus penelitian. Permasalahan yang pernah terjadi sebelumnya yaitu terkait pengklaiman kesenian reyog sebagai kekayaan budaya oleh negara asing menjadi sebuah hal ironi. Ini membuktikan bahwa masyarakat kurang memperhatikan dan mencintai kesenian reyog sebagai identitas lokal. Kurangnya upaya dalam mempertahankan dan melestarikan kesenian reyog menjadi salah satu pemicu dalam hal kasus pengklaiman yang terjadi. Dengan melakukan penelitian dan penulisan gemblak sejarah dapat membantu peserta didik dalam proses mendapatkan pengetahuan baru tentang upaya yang dilakukan sekelompok masyarakat pada masa lampau untuk menjaga dan melestarikan kesenian reyog. 
Modul ini dilengkapi dengan materi terkait teknikpenentuan sumber primer dan sekunder dari sejarah gemblak, pengumpulan dan pengolahan data sejarah, penafsiran, dan langkah-langkah atau sistematika penulisan sejarah dalam bentuk makalah. Selain itu, perancangan lembar kerja siswa turut dikembangkan guna menjadi wadah yang mengarahkan peserta didik dalam memahami setiap langkah penelitian dan penulisan sejarah. Adapun komponen modul terdiri dari 1) tujuan kompetensi, adapun kompetensi dari silabus yang menjadi Patokan yaitu: KD 3.7, "menganalisa metode sejarah pada berbagai peristiwa", dan KD 4.7, "melakukan penelitian sejarah secara sederhana dan menyusun hasil penelitian dalam bentuk laporan penelitian". Pada kompetensi dasar ini, pesera didik membutuhkan materi tambahan yang dapat membimbing mereka untuk melakukan penelitian dan penulisan sejarah: 2) deskripsi modul yang memberikan penjelasan tentang isi modul: 3) alokasi waktu dalampenggunaan modul, 4) instruksi pembelajaran yang mengarahkan peserta didik pada penggunaan modul, 5) tujuan akhir, 6) materi penelitian dan penulisan sejarah yang terdiri dari heuristik, kritik sumber, interpretasi, dan historiografi, 7) ringkasan, 8) tes formatif untuk mengukur keterampilan kognitif siswa, 9) lembar kerja yang memungkinkan siswa untuk kerja nyata, 10) penilaian diri, 11) tes evaluasi sebagai alat untuk mengevaluasi kompetensi siswa, dan 12) lembar jawaban.

\section{KESIMPULAN}

Menurut analisis kebutuhan siswa, guru, dan proses pembelajaran terhadap pengembangan bahan ajar penelitian dan penulisan sejarah, dapat disimpulkan bahwa: pertama, kebutuhan siswa terhadap bahan ajar pengayaan sejarah sangat tinggi. Ini menunjukkan bahwa peserta didik membutuhkan informasi yang lebih detail tentang pelajaran sejarah dalam rangka mendapatkan pemahaman yang mendalam. Dengan melakukan penelitian dan menulisan sejarah lokal Ponorogo memungkinkan peserta didik untuk meningkatkan keterampilan penyelidikan, pengumpulan dan proses data, dan menulis sejarah. Di sisi lain, produk ini dapat mendukung proses penanaman kesadaran sejarah pada diri peserta didik. Kedua, model pembelajaran berbasis proyek adalah strategi yang efektif untuk mendukung kegiatan pembelajaran. Hal ini dikarenaka, model ini mempunyai langkah-langkah pembelajaram yang memungkinkan peserta didik dalam membuat produk dalam bentuk artikel atau makalah. Ketiga, pemilihan sejarah gemblak sebagai studi kasus penelitian dipilih berdasarkan kondisi kultural peserta didik. Hal ini didasarkan pada rasa keingintahuan yang tinggi pada sejarah yang telah dilupakan oleh masyarakat Ponorogo.

\section{SARAN}

Berdasarkan hasil penelitian, perlu disampaikan saran untuk beberapa pihak, antara lain, (1) bagi pendidik, disarankan menggunakan bahan ajar pengayaan berdasarkan analisis kebutuhan peserta didik, kurikulum, dan kondisi pembelajaran serta mengintegrasikan sejarah lokal yang ada di lingkungan peserta didik. Selain itu, penggunaan bahan ajar perlu di dukung dengan model pembelajaran aktif yang telah direkomendasikan oleh kurikulum 2013 sebagai contoh model project-based learning, (2) bagi lembaga pendidikan atau sekolah, disarankan menyediakan sarana dan prasarana yang memungkinkan peserta didik untuk mempelajari sejarah lokal. Upaya yang dapat dilakukan adalah membuat

310 BRILIANT: Jurnal Riset dan Konseptual Volume 3 Nomor 3, Agustus 2018 
extrakurikuler terkait kesenian reyog, menyediakan ruang baca dengan refensi sejarah lokal dalam jumlah cukup, dan menciptakan suasana belajar yang kondusif, (3) bagi peserta didik, disarankan untuk lebih antusias dalam mengenal, memahami, dan mencintai budaya lokal sehingga kekayaan nenek moyang senantiasa terjaga dan menjadi pembelajaran bagi kehidupan mendatang.

\section{DAFTAR RUJUKAN}

Abdullah, T. 1985. Ilmu Sejarah dan Historiografi. Jakarta: Gramedia.

Daryanto. 2013. Menyusun Modul, Bahan Ajar Untuk Persiapan Guru Dalam Mengajar. Yogyakarta: Gava Media.

Hamid, A. 2015. Pengantar Ilmu Sejarah. Yogyakarta: Ombak.

Hosnan, M. 2014. Pendekatan Saintifik dan Konstektual Dalam Pembelajaran Abad 21, Kunci Sukses Implementasi Kurrikulum 2013. Bogor: Ghalia Indonesia.

Kuswono. 2017. Pengembangan Modul Sejarah Pergerakan Indoensia Terintegrasi Nilai Karakter Religius. Jurnal Historia, 5 (1): 31-44.

Ningsih, P.H. 2015. Pengaruh Penggunaan Modul dan Penggunaan Buku Paket Terhadap Prestasi Belajar Mata Pelajaran IPS Siswa Kelas V SDN Sukabumi 10. JPPI, 9 (2): 1210-1218.

Notosusanto, N. 1975. Mengerti Sejarah. Jakarta: Yayasan Pendidikan Indonesia.

Novianti, dkk. 2014. Pengembangan Bahan Ajar Sejarah Berupa Cerita Rakyat Sebagai Wujud Kearifan Lokal. Jurnal Studi Sosial, 2 (4): 1-12.

Oguzan, K. 2015. Teaching Local History Using Social Studies Models For Turkish Middle School Students. Academic Journals of Educational Research and Reviews, 10 (8): 1284-1292.

Permana, N. 2016. Pemakaian Modul Pembelajaran Sejarah di SMAN 6 Padang. Jurnal Pendidikan Sejarah, 5 (2): 42-53.

Retnawati, H. 2017. Improving Understanding Of Research Methodology and Self Regulated Learning Through Blog Project. Cakrawala Pendidikan, 36(2): 180-191.

Romadi \& Ganda, F. 2017. Pembelajaran Sejarah Lokal Berbasis Folklore Untuk Menanamkan Nilai Kearifan Lokal Kepada Siswa. Sejarah Dan Budaya, 11 (1): 79-94.

See, YA. 2015. The Effect of Project-Based Learning on the level of Content Knowledge of Pre-Vocational Subject. Mediterranean Journal of Social Sciences, 6 (6): 369-375.

Smith, N. 2010. History Teacher's Handbook. London: CPI Antony Rowe.

Suharso. 2017. Pembelajaran sejarah lokal pada kelas sejarah (model pengembangan bahan ajar sejarah lokal Kota Kudus dalam rangka meningkatkan minat siswa pada sejarah. Jurnal Sejarah dan Budaya, 11 (1): 199-211.

Thiagaran, SS 1974. Instructional Development For Training Teachers of Exceptional Children: A sourcebook. Bloomington: Indiana University.

Thitivesa, D. 2014. The Academic Achievement of Writing Via Project-Based Learning. International Journal Of Economics and Management Engineering, 8(9): 2994-2997.

Thompson, P. 2012. Suara Dari Masa Silam, Teori dan Metode Sejarah Lisan. Yogyakarta: Ombak. 